\title{
Monetary Factors and Inflation in Japan
}

Katrin Assenmacher-Wesche, Stefan Gerlach and Toshitaka Sekine

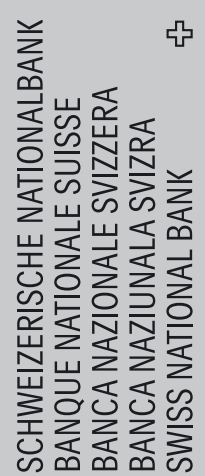

(1)

(4)

O

ro

( 
The views expressed in this paper are those of the author(s) and do not necessarily represent those of the Swiss National Bank. Working Papers describe research in progress. Their aim is to elicit comments and to further debate.

ISSN $1660-7716$

๑ 2007 by Swiss National Bank, Börsenstrasse 15, P.0. Box, CH-8022 Zurich 


\title{
Monetary Factors and Inflation in Japan
}

\author{
Katrin Assenmacher-Wesche ${ }^{*}$ \\ Research Department \\ Swiss National Bank \\ Stefan Gerlach \\ Institute for Monetary and Financial Stability \\ Johann Wolfgang Goethe University, Frankfurt \\ Toshitaka Sekine \\ Monetary Affairs Department \\ Bank of Japan
}

October 5, 2007

\begin{abstract}
Recently, the Bank of Japan outlined a "two perspectives" approach to the conduct of monetary policy that focuses on risks to price stability over different time horizons. Interpreting this as pertaining to different frequency bands, we use band spectrum regression to study the determination of inflation in Japan. We find that inflation is related to money growth and real output growth at low frequencies and the output gap at higher frequencies. Moreover, this relationship reflects Granger causality from money growth and the output gap to inflation in the relevant frequency bands.
\end{abstract}

Keywords: spectral regression, frequency domain, Phillips curve, quantity theory. JEL Numbers: C22, E3, E5

The views expressed are solely our own and are not necessarily shared by the SNB or the BOJ. We are grateful to Helge Berger, Mathias Hoffmann, Carlos Lenz, the editor and two anonymous referees, the editors of the SNB Working Paper Series and seminar participants at the SNB, the FU Berlin and the University of Zürich for helpful comments. Contact information: Katrin Assenmacher-Wesche (corresponding author): SNB, Börsenstrasse 15, Postfach 2800, CH-8022 Zürich, Switzerland, Tel +41 44631 3824, email: Katrin.Assenmacher-Wesche@snb.ch; Stefan Gerlach: Mertonstrasse 17, D-60325 Frankfurt/Main, Germany, email: Stefan.Gerlach@wiwi.uni-frankfurt.de; Toshitaka Sekine: Bank of Japan, Chuo-ku, Tokyo 103-8660, Japan, Tel +81 33277 2877, email toshitaka.sekine@boj.or.jp. 


\section{Introduction}

The role monetary aggregates should play, if any, in the conduct of monetary policy remains a controversial issue. While no major central bank relies on monetary targeting, both the European Central Bank and the Swiss National Bank attach considerable weight to monetary variables, in particular broad aggregates, in analysing and forecasting inflation. Of course, this practice reflects the fact that in both economies shocks to velocity have historically tended to be small. Indeed, research on the relationship between money growth and inflation in these economies, in the form of estimated money-demand relationships or models for forecasting inflation, typically have not found much evidence of instability over time. By contrast, in the United States, where shifts to velocity have been large and unpredictable, money plays no role in the framework of monetary policy. Indeed, the Federal Reserve recently decided to cease compiling M3 data.

In this paper we study the relationship between money growth and inflation in Japan. Doing so is interesting for several reasons. First, Japan has experienced large fluctuations in the rate of inflation in the post-1970 data we consider. Measured in terms of changes over four quarters, inflation peaked in 1974 in Japan at about 25\% and reached a trough in 2002 of -1.4\%. Bordo and Filardo (2005 and 2007) study the inflation experiences of a large number of countries since the late $19^{\text {th }}$ century and conclude that while money growth is generally not a useful information variable for inflation in episodes in which it is low and stable, it does contain useful information in periods of high inflation and deflation. One would for this reason expect to find quite a strong relationship between money growth and inflation in Japan. Indeed, as we discuss below, there is a large empirical literature finding strong linkages between money and prices in Japan, although the stability of these relationships remains an unsettled issue.

Second, empirical linkages between money and prices have played an important role in the thinking about monetary policy by the Bank of Japan (BOJ). While the BOJ did announce a quarterly forecast for money growth as measured by M2 plus Certificates of Deposit (M2+CD) between 1978 and 2006, it never targeted money growth. Rather, the monetary policy framework in force since the early 1970s can arguably best be described as an eclectic monetary policy strategy characterised by an absence of an intermediate target and a numerical ultimate target for policy but with some importance being attached to money 
growth. ${ }^{1}$ This view is illustrated by a remark made by Governor Mieno in testimony to the Diet in May 1987: "We have paid attention to the developments of the money supply, as history not only in Japan but also in other countries suggests that in the long run a higher money growth rate tends to result in a higher inflation rate. Nevertheless, the relationship between money and inflation is much more complicated than a simple causal relationship implying that a certain rate of money growth will always result in a specified rise of inflation. For this reason, it is very difficult to determine the appropriate level of monetary aggregates and we need to rely on overall judgment based on all available information at the time" (authors' translation). Monetary aggregates became more important when the conduct of policy changed dramatically as a consequence of the episode of quantitative easing between March 2001 and March 2006, during which the level of base money constituted the operational target for policy. ${ }^{2}$

Broadly speaking, the role of money in monetary policy has been the subject of intensive policy discussion in Japan on three occasions. The first of these was in the 1970s when it was argued (e.g., Komiya 1976) that it was not the supply shock stemming from rapid oil-price increases but "excess liquidity" created by the BOJ that was responsible for the surge in inflation in 1973-1974. The next occasion was in the early 1990s when some observers asserted that the main cause of the formation and bust of the asset-price bubble in the late 1980s and early 1990s was the fact that the BOJ initially let the money supply grow excessively and subsequently reduced the growth rate sharply. ${ }^{3}$ The final episode started around 2000 when Japan faced deflation and short-term interest rates reached the zero lower bound. At that time some analysts advocated the adoption of monetary targeting (e.g., Meltzer 2001 and Hetzel 2004) while others were sceptical (e.g., Krugman 1998, Eggertsson and Woodford 2003 and Svensson 2003).

These conflicting views resulted in an intense policy debate about what weight the central bank should place on money in its policy strategy as well as how it should interpret the signals from movements in the monetary aggregates. Reconsidering the role of money in monetary policy in Japan is also warranted by the fact that while monetary relationships may

\footnotetext{
A senior BOJ official (Suzuki 1985) referred to the BOJ's approach as "eclectic gradualism."
}

2 Under the quantitative easing policy, the operational target was the banks' current account balances, which constitutes a major part of base money. In addition, in October 2003, the BOJ committed to a specific inflation rate by stating that it would not lift the quantitative easing policy until core CPI inflation rate turned positive.

3 See the debate between Iwata (1993) and Okina (1993). 
have shifted during the recent episodes of financial instability and zero interest rates, they may now be undergoing a "normalisation" (Iwata 2006), as interest rates start rising.

In analysing the relationship between money growth and inflation in Japan this study follows a number of recent papers that demonstrate that the relationship between money growth and inflation varies across frequency bands or, loosely speaking, "time horizons". AssenmacherWesche and Gerlach $(2006,2007 a)$ use spectral regression techniques to demonstrate that there is close relationship between money growth and inflation in the euro area but only at frequencies corresponding to periodicities of more than four years. Furthermore, this relationship reflects unidirectional Granger causality from money growth to inflation. Thus, money growth can heuristically be thought of as determining the "trend" of inflation. They also show that at higher frequencies, output gaps and, at the highest frequencies, import price shocks, cause inflation. Assenmacher-Wesche and Gerlach (2007b) show that similar relationships are present in Swiss data. Interestingly, these results are strikingly compatible with views of the inflation process of the European Central Bank and the Swiss National Bank, which both attach importance to broad money growth as a determinant of long-run inflation while recognising that the state of the business cycle and cost-push shocks have important transitory effects on inflation. ${ }^{5}$

The paper is structured as follows. In the next section we provide an overview of the role played by monetary aggregates since the early 1970s in the Bank of Japan's thinking about policy. Historically, large movements in money growth have been seen as signalling major changes in the path of aggregate demand. We also provide a brief review of the literature on the relationship between money and inflation in Japan. The key finding in that literature is that, although the recent data has not been fully examined yet, money-demand relationships are generally stable if properly specified and that money growth does contain information useful for forecasting future inflation.

In Section 3 we present our econometric model, which follows Assenmacher-Wesche and Gerlach (2006). We assume that inflation can be decomposed into low- and high-frequency components. At low frequencies, inflation is determined by the flow excess supply of money,

4 A time series at any point in time consists of both high and low-frequency components and thus there is no direct correspondence between frequencies and time horizons. While high-frequency fluctuations per definition cannot have long-run effects, the low-frequency components are present in the short and the long run.

5 This view of the inflation process has been formalised in the time domain by Gerlach (2003 and 2004), Neumann (2003), and Neumann and Greiber (2004). 
defined by the growth rate of money minus the growth rate of real GDP and changes in interest rates that capture shifts in money demand. At high frequencies inflation is caused by the output gap.

In Section 4 we review the data and consider time-series plots of the relationships between money growth and inflation in Japan across frequency bands. These suggest that at low frequencies money growth leads inflation. In Section 5 we turn to the econometric results. The analysis in this section follows that of Assenmacher-Wesche and Gerlach (2007c) which demonstrates that this frequency-band decomposition is useful for understanding the determination of inflation also in Japan. ${ }^{6}$ We show that there are close linkages between inflation on the one hand, and money growth and output growth on the other. Furthermore, these linkages are closer at low than at high frequencies. We also show that the opportunity cost of holding broad money in Japan is better modelled by using the logarithm of interest rates, rather than interest rates themselves. Finally, we demonstrate that headline inflation can be modelled by focusing on the low-frequency variation of money growth and output growth - the quantity theoretic variables - and the output gap.

In Section 6 we go on to show that the correlations between money growth and inflation, and the output gap and inflation, in the relevant frequency bands reflect unidirectional Granger causality from money growth and the output gap to inflation. Finally, Section 7 offers our tentative conclusions.

\section{Money and monetary policy in Japan}

On 9 March 2006, the Bank of Japan lifted its quantitative easing policy and adopted a new monetary policy framework. Under the new framework, the BOJ outlined a "two perspectives" approach to the conduct of monetary policy. The first of these is an evaluation of the stance of policy in the light of expected developments in economic activity and inflation over a one-to-two-year horizon. Particular emphasis is placed on examining whether the Bank's outlook, which is published biannually, is consistent with sustainable growth under the BOJ's Policy Board's understanding of price stability (currently, 0-2\% CPI inflation). The second perspective is meant to address risks to sustainable growth and price

6 While these authors show that the same decomposition fits the US data, the low-frequency link between money growth and inflation is much less distinct in the US than in Japan and in the euro area. In the case of the UK, there appears to be no causality from money growth to inflation. 
stability over a longer horizon that might require more flexibility in the conduct of policy than would be implied by the first perspective alone.

While the "two perspectives" bear some similarities with the European Central Bank's "two pillar" approach in that both strategies would potentially allow departures from short to medium-run inflation control, the role of money is very different in the two frameworks. ${ }^{7}$ While the ECB specifies a reference value for the growth of M3, the BOJ does not provide an explicit role for the money stock in its conduct of monetary policy. Indeed, the background document of the new policy framework does not refer to "money" at all (BOJ, 2006).

This omission of an explicit role for money seems to reflect the fact that the BOJ no longer perceives monetary aggregates to provide useful information about future inflation. By contrast, it used to see money as an important indicator when it started to announce forecasts on money growth in the late 1970 s. $^{8}$ At the time, the BOJ appeared to think that although money might not predict small fluctuations of economic activity, a large change in the money stock would convey important signals of major shocks affecting the economy. ${ }^{9}$ However, more recently, the BOJ (2003) interpreted the fact that the episode of deflation coincided with modest $\mathrm{M} 2+\mathrm{CD}$ growth as an indication that the relationship between these variables had become unstable after the mid-1990s. As a result, it stated that

"In the current circumstances, it is difficult to obtain information about current and future economic developments or prices and furthermore about the effect of monetary policy from movements in the money stocks." (BOJ, 2003, p. 168).

Iwata (2006) argues that the link between money, output and prices largely disappeared after 1997 as a consequence of weakness in the financial sector.

Empirical research so far is generally compatible with the BOJ's view. First, earlier work broadly suggests that the relationship between money and economic activity has been stable and that money contains information useful for forecasting future inflation. For instance, analyses of the stability of money-demand functions tend to find that if variables representing wealth effects and/or precautionary demand are controlled for, there is little evidence of a

7 Interestingly, the "two perspectives" approach was referred to by the BOJ as the "two pillar" approach in Japanese in the original documents.

8 Iwata (2006) and BOJ (2003) review the BOJ's thinking about the role of money in monetary policy since the 1970 s.

9 Examples of such shocks are the episodes of rapid inflation in the early 1970s and the formation and bust associated with the "bubble economy" in the late 1980s and early 1990s. 
shift in money demand (e.g., Sekine 1998 and Kimura 2001). ${ }^{10}$ In addition, money indeed seems to be a useful policy indicator when forecasting inflation in Japan. For instance, Sekine (2001) shows that deviations from a long-run money demand relationship are relevant for forecasting future inflation. Kitamura and Koike (2003) demonstrate that inflation forecasts can be improved by adding money growth as an explanatory variable.

However, consistent with the BOJ's view, more recent work points to a change in the relationship between money growth and inflation. For instance, Miyao (2005) reports that regression coefficients on money growth have become insignificant in forecasting equations for inflation and real GDP growth estimated on data from the 1993-2003 period. Kimura, Kobayashi, Muranaga and Ugai (2003) estimate a time-varying-parameter vector autoregression (VAR) consisting of the output gap, the overnight call rate, the inflation rate and base money growth. Comparing the impulse responses in 1985 and 2002, they observe that an increase in the monetary base had a positive effect on inflation in 1985, but not in 2002. By estimating a Markov-switching VAR, Fujiwara (2006) also shows that the positive impact of an increase in base money on prices disappeared under the zero-interest-rate regime that started in February 1999.

However, money growth may contain information useful for understanding inflation developments despite these findings. First, the latter two papers examine the effect of changes in base money under the quantitative monetary easing policy rather than the behaviour of the measure of broad money we study in this paper. ${ }^{11}$ Given the decline in the credit multiplier which resulted from widespread problems in the financial sector, it is possible that the relationship between narrow and broad money has become unstable while the relationship between inflation and broad money has remained stable. Second, although the relationship between money and inflation at high frequencies may have changed, at low frequencies the relationship might remain intact. Finally, after Japan abandoned the quantitative easing strategy and the non-performing loan problem started to subside, the earlier money-inflation relationship may have been restored. In fact, the BOJ (2003, p. 169) foresaw that this might

10 A large amount of research examines the stability of money demand in Japan with inconclusive results. For instance, Miyao (1996) and Nagayasu (2003) argue that the cointegrating relationship for broad money demand that could be established in older data disappeared in the late 1980s or the early 1990s. Recently, Miyao (2002), Fujiki and Watanabe (2004) and Bae, Kakkar and Ogaki (2006) show that, at least for the demand for M1, a stable cointegrating relationship remains even after adoption of the zero-interest-rate regime in 1999 once the logarithm of interest rates is used to capture the opportunity cost of holding money.

11 For a survey of the quantitative easing policy and its effects, see Ugai (2006). 
happen and stated that "[in the future] it would not be unreasonable to expect large fluctuations in the money stock to once again imply large fluctuations in economic activity." Note that if disturbances to the money-growth-inflation relationship are reasonably short-lived, the relationship may remain stable at low frequencies.

\section{An empirical model of inflation}

In this section we present a small, reduced-form empirical model of the inflation process. The first perspective of the BOJ focuses on expected developments in economic activity over a horizon of up to two years, whereas the second perspective addresses risks to price stability in the long run. To formalize this view, we first decompose "headline" inflation, $\pi_{t}$, into low$(L F)$ and high-frequency $(H F)$ components:

$$
\pi_{t}=\pi_{t}^{L F}+\pi_{t}^{H F}
$$

Following Gerlach (2003, 2004), we hypothesise that the high-frequency movements of inflation are related to movements in the output gap, $g_{t}$. As is common in the literature, we assume a time lag of one period between the variables: ${ }^{12}$

$$
\pi_{t}^{H F}=\alpha_{g} g_{t-1}+\varepsilon_{t}^{H F}
$$

While the BOJ is not explicit about the forces that affect inflation over the long run, we follow Lucas (1980) and assume that the low-frequency variation of inflation can be understood in terms of the quantity theory of money, where again we lag the explanatory variables by one period:

$$
\pi_{t}^{L F}=\alpha_{\mu} \mu_{t-1}^{L F}+\alpha_{\gamma} \gamma_{t-1}^{L F}+\varepsilon_{t}^{L F}
$$

Here, $\mu_{t}$ and $\gamma_{t}$ denote the growth rate of money and real output, and $\varepsilon_{t}^{L F}$ captures shocks to low-frequency velocity. At low frequencies, the growth rate of real output is identical to the growth rate of potential. Under the quantity theory, and provided that money growth is uncorrelated with velocity shocks at low frequencies (that is, $\mu_{t}^{L F}$ and $\varepsilon_{t}^{L F}$ are orthogonal), we expect that $\alpha_{\mu}=-\alpha_{\gamma}=1$. Here we interpret the second perspective as an approach to understanding low-frequency movements, or variations in the "local steady-state" rate, of inflation. Similarly, we view the analysis of the real indicators (the first perspective) as an

12 In the empirical analysis we subtract the sample means from all variables and therefore do not include constants in the equations. 
approach to predicting short-run swings in inflation around that steady state. The full model of the inflation process is thus given by:

$$
\pi_{t}=\alpha_{g} g_{t-1}+\alpha_{\mu} \mu_{t-1}^{L F}+\alpha_{\gamma} \gamma_{t-1}^{L F}+\varepsilon_{t}
$$

where $\varepsilon_{t}=\varepsilon_{t}^{L F}+\varepsilon_{t}^{H F}$. Under this interpretation of the BOJ's policy strategy, it seems appropriate to focus on low-frequency movements in money growth and output growth, and on the output gap in analysing inflation.

The main reason for why money growth is often, if not typically, regarded as an unreliable indicator of inflation is the occurrence of shifts in velocity, which tend to arise as a consequence of financial deregulation and changes in interest rates. This suggests that the information content of money growth for inflation could be enhanced by controlling for shifts in velocity arising from changes in interest rates. While this can be done at any (or all) frequency bands, here we adjust money growth in the low-frequency band, $\mu^{L F}$, for changes in interest rates in the same frequency band, $\rho^{L F}$,

$$
\tilde{\mu}_{t}^{L F}=\mu_{t}^{L F}-\hat{\alpha}_{r} \rho_{t}^{L F}
$$

The coefficient $\alpha_{r}$ is the long-run interest elasticity of money demand, which we estimate by regressing real money, $m-p$, on real output, $y$, and the money market interest rate, $r$ :

$$
m_{t}-p_{t}=\alpha_{y} y_{t}+\alpha_{r} r_{t}+\varepsilon_{t}^{m}
$$

Of course, this procedure does not control for changes in velocity arising from financial innovation, so that the issue whether money growth is informative for inflation remains. ${ }^{13}$

Besides the low-frequency component of actual money growth, $\mu^{L F}$, we also use "interest-rate adjusted" (or "adjusted" for short) low-frequency money growth, $\widetilde{\mu}^{L F}$, as a regressor in the inflation equations we estimate below. Another strategy would be to directly include an interest rate in the reduced-form inflation equation. However, the potential endogeneity of interest rates, which arises either if short-term interest rates are set in response to inflation or if inflation impacts on expected inflation and therefore on long-term interest rates,

13 The estimate of $\alpha_{r}$ will only be unbiased if shocks to velocity arising from financial innovations are uncorrelated with the explanatory variables in the money demand equation. 
complicates estimation. To overcome this problem we use both a two-step estimation approach and estimate a system consisting of the money-demand and inflation equations. ${ }^{14}$

\section{Data}

We use quarterly data from 1970 to the end of 2005. Inflation is measured as the $\log$ difference of the CPI, money is M2+CD. Output is measured by splicing the series for real gross domestic expenditure (GDE), calculated according to the System of National Accounts from 1993 (SNA93), with the one compiled by the SNA68 methodology in 1994. The interest rate is the money-market rate (call rate).

Figure 1 shows the data. Inflation declined throughout the sample period from a peak around 1973 to low and even negative rates in the 1990s. The evolution of inflation over the sample period is reflected in money growth. The high money growth and the subsequent rise in inflation in the early 1970s correspond to the episode of excess liquidity. By contrast, both monetary growth and inflation remained modest after the second oil-price shock in 1979. This experience led Friedman (1985) to state that "The Bank of Japan has been the least monetarist central bank in its rhetoric, the most monetarist in its policy. It has also achieved the best results". ${ }^{15}$ In the late 1980s and early 1990s, while inflation remained broadly stable (especially if we exclude the effects of the introduction of, and the increase in, the consumption tax in 1989 and 1997), the money-growth data reflect the formation and the burst of the bubble in Japanese asset markets around $1990 .{ }^{16}$ After that, both money growth and inflation remained low despite the aggressive quantitative easing after 2001.

Interest rates show marked movements in the early part of the sample but were virtually constant after 1995 when the target overnight call rate was cut to below $0.5 \%$. The literature on money demand in Japan has shown that the opportunity cost of holding money might be better captured by the logarithm of the interest rate than by the usual semi-log specification (Miyao 2002, Fujiki and Watanabe 2004). The second row in Figure 1 therefore shows the

14 Our approach only requires us to assume, as is common in the large literature on estimating money demand, that interest rates are predetermined relative to the real money stock.

15 Recently, Nelson (2006) attributes this success to the recognition by the Japanese government and the BOJ that inflation is a monetary phenomenon.

16 The combination of high money growth and stable inflation in the late 1980s puzzled the BOJ. At that time, Governor Mieno said that the rapid expansion of money stock made him feel like "sitting on dried firewood." However, the BOJ kept its policy interest rate low until 1989 since there was no evidence of rising inflation. 
interest rate and the log interest rate in levels (left panel) and differences (right panel). ${ }^{17}$ It is evident that considering the logarithm of the interest rate does have a sizable effect on the evolution of the opportunity cost of holding money, especially when the sample includes the recent period of low interest rates.

Next we turn to the output gap (defined as output relative to a smooth trend). To construct a measure of the trend output, we extract all variation of frequencies of more than 48 quarters from the quarterly growth rate of real output. Converting the filtered series to the time domain and accumulating the filtered growth rate over time, we obtain a measure of the level of potential. The resulting output gap, which is plotted in the bottom left-hand panel of Figure 1, is very similar to the Hodrick-Prescott (HP) filtered output gap, as indicated by the correlation coefficient of $0.95 .{ }^{18}$ Finally, since the series on real output growth is rather volatile, we present it together with a centred five-quarter moving average to make it easier to see how money growth and output growth are related. The graph shows that output growth was high in the 1970s and 80s but subsequently fell and fluctuated around zero thereafter. More importantly, the swings in money growth in the 1970s and the fall in money growth at the beginning of the 1990s seem to coincide with similar movements in output growth.

Before turning to the empirical analysis it is useful to consider the statistical properties of the data, in particular their unit-root behaviour. As unit-root tests are known to have low power in the case of a root close to unity, we employ several tests. ${ }^{19}$ The lag length is chosen by the Schwarz information criterion (SIC). As can be seen from Table 1, output growth, the output gap and the change in the log interest rate can be regarded as stationary. ${ }^{20}$ While money growth appears to be nonstationary, inflation is stationary according to the Phillips-Perron (PP) and the Elliot, Stock and Rotenberg (ERS) tests but nonstationary according to the Augmented Dickey Fuller (ADF) and the KPSS tests.

As pointed out by a referee, this result suggests an inconsistency between the time series behaviour of inflation and money growth since economic theory implies that both variables

17 To make the magnitude of log interest rate changes comparable to money growth and inflation rate, we divided the log of the interest rate in percent by 100 .

18 The empirical results are unaffected if we use the HP-filtered output gap instead of the output gap calculated with the spectral filter.

19 Whereas the ADF test, the PP test and ERS test have the null hypothesis that the variable tested is nonstationary, the null hypothesis for the KPSS test is stationarity. The unit root tests are discussed in Maddala and Kim (1998).

20 The econometric analysis in this paper was done with RATS $6.02 \mathrm{~b}$. 
should be integrated of the same order if output growth and shocks to velocity are stationary. There are three possible reactions to this finding.

First, unit-root tests are known to have low power and may falsely accept the null hypothesis of nonstationarity though money growth is in fact stationary. The fact that real money growth is indeed stationary supports this hypothesis.

Second, money growth could be stationary but with a shift in the level of the series. In this case, unit-root tests may not be able to distinguish between a stochastic trend and a stationary behaviour around a changing mean. Indeed, the unit-root test by Lee and Strazicich (2003, 2004) indicates that money growth can be regarded as stationary with a break in the intercept. ${ }^{21}$ If so, one would expect output growth and inflation to show similar shifts in level, but since both series are quite volatile, it may be more difficult to detect such level shifts in these series. However, if shifts existed and cancelled, the change in velocity and real money growth should be stationary, which is confirmed by the test results in Table 1.

Third and finally, money growth and inflation could be $I(1)$ and be cointegrated, causing real money growth to be stationary. In this case, the point estimates for the low frequency band regressions that are presented below would not be affected, but we would have to use instrumental-variables estimation for the high-frequency band. ${ }^{22}$ Furthermore, if money growth and inflation are nonstationary, but output growth is not, the coefficient on output growth in the low-frequency regression in Table 2 should approach zero. Since there is little evidence of this, we do not consider this scenario as likely.

To see how the empirical model in Section 3 will fit the data, we plot inflation, money growth and the output gap in different frequency bands. Figure 2 shows the relation between inflation and money growth at low and high frequencies. Following Baxter and King (1999) we define low frequencies as containing fluctuations with a periodicity of more than 32 quarters, while high frequencies contain fluctuations with periodicities between 6 and 32 quarters. At low frequencies inflation and money growth are positively correlated but at high frequencies the

21 Surprisingly, the most likely break date is 1976Q2, and only when two breaks are allowed 1990Q1 is picked as the second break date. GAUSS programs for unit root tests with one or two endogenous breaks were obtained at http://www.cba.ua.edu/ jlee/gauss/.

22 Following Assenmacher-Wesche and Gerlach (2006), we also estimated the models allowing for nonstationary variables but the results were so similar to those presented here that we do not report them. 
correlation is negative. ${ }^{23}$ Moreover, in the first part of the sample peaks in money growth seem to lead peaks in inflation by two to three years, whereas peaks are less marked and occur simultaneously in the later part of the sample. Figure 3 shows the relation between the output gap and inflation at low and high frequencies. While there is a positive relation at the business-cycle frequency, the output gap does not explain the low-frequency movements in inflation.

\section{Empirical methods and results}

\subsection{Money demand estimation}

The first step in the analysis is the estimation of a money demand function to obtain the longrun interest elasticity of money demand which is needed to compute adjusted money growth. We use Dynamic Ordinary Least Squares (DOLS) as proposed by Stock and Watson (1993), include two leads and lags of the differenced regressors and apply an AR(4) correction to the errors. $^{24}$ To check stability, we compute the coefficient on the interest rate recursively. Figure 4 shows that the coefficient on the interest rate decreases once the sample is extended beyond 1997. ${ }^{25}$ By contrast, the coefficient on the logarithm of the interest rate appears to be reasonably stable. This agrees with the results by Miyao (2002) and Fujiki and Watanabe (2004) who find that a log-log specification of money demand is stable for Japan. Moreover, Bae, Kakkar and Ogaki (2006) compare different functional forms in a non-linear cointegration framework and find that a log-log specification performs well. We therefore use the latter estimate of the long-run interest elasticity of money demand to correct lowfrequency money growth for shifts in velocity induced by changes in interest rates.

\subsection{Band spectrum regression}

In this section we estimate band spectrum regressions, which allow the relation between a set of variables to differ between frequencies. This technique is particularly appropriate for the present case, in which we hypothesise that the output gap matters for inflation at high

23 The negative correlation is smaller if money growth adjusted for interest rate changes is used. This suggests that the correlation may be due to velocity reacting to changes in policy-controlled interest rates in response to movements in inflation.

24 Though velocity is nonstationary, the residuals from a regression of velocity on the log interest rate and a trend are stationary with a test statistic of $-3.85(p$-value $=0.05)$.

25 Estimating the long-run interest elasticity by an Autoregressive Distributed Lag (ARDL) model (see Pesaran and Shin 1998) gives similar results and does also not indicate problems with instability when the logarithm of the interest rate is used. 
frequencies, while money and real output growth are correlated with inflation only at low frequencies. Corresponding to the two-perspective view of the BOJ, in the empirical work below we draw the distinction between the low and the high-frequency bands at a periodicity of two years. Nevertheless, in the two-year frequency band money growth still may contain considerable noise (as suggested by the results for the euro area reported in AssenmacherWesche and Gerlach (2006)), and we therefore repeat our analysis for a split at the four-year frequency.

Engle (1974) shows that if $y=x \beta+\varepsilon$ is a valid regression model in the time domain, it can be transformed into the frequency domain by applying a Fourier transformation to both the dependent and the independent variables. Denoting the transformed variables as $\tilde{x}$ and $\tilde{y}$, the regression in the frequency domain is $\tilde{y}=\tilde{x} \beta+\widetilde{\varepsilon}$. The transformation to the frequency domain does not affect the standard regression results. The estimator, $\hat{\beta}$, can be written as:

$$
\hat{\beta}=\left[\sum_{k=0}^{T-1} \hat{f}_{x x}\left(\omega_{k}\right)\right]^{-1} \sum_{k=0}^{T-1} \hat{f}_{x y}\left(\omega_{k}\right),
$$

where $T$ is the sample size, $\hat{f}_{x x}(\omega)$ is the periodogram of the series in $x$ at each frequency $\omega$ and $\hat{f}_{x y}(\omega)$ is a vector of cross periodograms. ${ }^{26}$ The benefit of transferring the regression model into the frequency domain is that it permits a test of the hypothesis that a specific model applies to some but not to all frequencies. In this case we premultiply the regression model by a $T \times T$ matrix $A$ with unity on the diagonal for each included frequency and zero elsewhere,

$$
A \widetilde{y}=A \widetilde{x} \beta+A \widetilde{\varepsilon}, \text { where } E(A \widetilde{\varepsilon})(A \widetilde{\varepsilon})^{*}=\sigma^{2} A
$$

with an asterisk, “*”, denoting the complex conjugate of the transposed matrix. Thus, to compute $\hat{\beta}$ we sum over a frequency band instead of the full range of frequencies as in equation (7). ${ }^{27}$ If equation (7) is estimated only for a subset of frequencies, but is true for all frequencies, the estimator is consistent but inefficient as it does not use all available information. By contrast, if the model applies only to a specific frequency band, using

\footnotetext{
26 Since the estimator of $\beta$ averages over periodograms, there is no need to smooth these as is necessary when estimating the spectrum.

27 Though the cross-periodograms in equation (7) are complex, $\hat{\beta}$ will be real if the $k^{\text {th }}$ frequency component is included along with the $T-k^{\text {th }}$ component.
} 
information from all frequencies might obscure the relationship between the variables. For example, if only low-frequency shifts in money growth lead to proportional increases in inflation, confining the regression to this frequency band is likely to lead to more efficient estimates of the coefficient on money growth. Engle (1974) shows that a conventional $F$-test can be used to test for equality of the parameters across frequency bands.

The upper panel in Table 2 presents the results from band spectrum regressions for the low and high-frequency band with the distinction drawn at the two-year frequency whereas the bottom panel shows the same regressions with a split at the four-year frequency. The first column shows the results from a regression of the low-frequency part of inflation on lowfrequency money and real output growth and the output gap. If the matrix $A$ in equation (8) is not full rank, we have to adjust the degrees of freedom in the regression by the number of frequencies that has been filtered out. The coefficient on low-frequency output growth is minus unity whereas the point estimate for low-frequency money growth is slightly below unity. A $F$-test that the coefficients are unity and minus unity yields a test statistic of $F_{2,32}=$ 4.06 and rejects this hypothesis at the 5\% level of significance but not at the $1 \%$ level. The low-frequency part of the output gap is significant, which is not surprising since the two-year split is above the business-cycle frequency. The second column in Table 2 shows that the results hardly change when adjusted money growth is used. Since in the calculation of adjusted money growth the estimated interest elasticity from the first-step money-demand regression is used, this approach yields inconsistent estimates for the covariance matrix of the coefficients. We therefore correct the standard errors following the approach of Murphy and Topel (1985).

To check robustness we also present results for a system that comprises the inflation equation and the money-demand equation, imposing the cross-equation restriction on $\alpha_{r}$. Since real $\mathrm{M} 2+\mathrm{CD}$, real output and the interest rate are nonstationary, we chose an autoregressive distributed lag (ARDL) model for the money-demand equation in the system, which is valid in the case of cointegrated $I(1)$ variables and provides a convenient way to implement the cross-equation restriction on the interest elasticity, see Pesaran and Shin (1998). ${ }^{28}$ To account for possible endogeneity we use lagged output and lagged changes in the low-frequency interest rate as instruments in the money-demand equation. The third column in Table 2

\footnotetext{
28 We include 4 lags of real money, one lag of output and no lag for the interest rate, which is the specification recommended by the Schwarz criterion, considering a maximum of 8 lags for each variable.
} 
reports the coefficients of the inflation equation in the system. Results remain qualitatively the same though the coefficient on low-frequency output growth is somewhat higher.

The next three columns in Table 2 show the results for the high-frequency band. As expected, money growth and output growth have no significant impact on high-frequency inflation, whereas the output gap generally has. Again, the estimates with the three different approaches are virtually identical.

The bottom panel of Table 2 shows the same regressions for a split at the four-year frequency. As expected, the coefficient on money growth is closer to its theoretical value of unity as higher frequencies are excluded. A $F$-test of the hypothesis that the coefficients on money growth and output growth are unity and minus unity, respectively, yields a $p$-value of 0.23 for the regression using unadjusted money growth and $p$-value of 0.07 for the regression using adjusted money growth. Since business-cycle fluctuations in this case are excluded in the lowfrequency band, the output gap is insignificant. Again, the results from the joint estimation of the inflation equation and the money-demand function yield the same result, except that the output gap still is significant at low frequencies. At the high-frequency band unadjusted money growth is significant but with the wrong sign, whereas adjusted money growth is not. ${ }^{29}$ Apart from that, results are the same as before and therefore we do not discuss them.

\subsection{A two-pillar Phillips curve}

The band spectrum regressions discussed above show that the relation between inflation, money and output growth and the output gap varies by frequency. Money growth seems to be important only at low frequencies, whereas the output gap contains information about inflation at both low and high frequencies. To proceed, we follow Gerlach $(2003,2004)$, Neumann (2003) and Neumann and Greiber (2004) and estimate an equation for headline inflation with the output gap and the low-frequency components of money growth and output growth as explanatory variables. In contrast to the regressions in the last section, the dependent variable is in this case not filtered and there is therefore no loss of degrees of freedom. To account for autocorrelation in the residuals we include four lags of the dependent variable. Our final inflation equation, which Gerlach $(2003,2004)$ refers to as "two-pillar Phillips curve", is thus:

\footnotetext{
29 One reason for this finding is that faster money growth and higher inflation led the BOJ to raise interest rates, which in turn depressed money growth,
} 


$$
\pi_{t}=\beta_{\mu} \mu_{t-1}^{L F}+\beta_{\gamma} \gamma_{t-1}^{L F}+\beta_{g} g_{t-1}+\sum_{i=1}^{4} \beta_{\pi i} \pi_{t-i}+\varepsilon_{t}
$$

Table 3 presents estimates of equation (9) using the unadjusted and the adjusted money growth rate. ${ }^{30}$ Furthermore it also presents system estimates of equations (6) and (9). The first three columns define the low-frequency band as containing fluctuations with a periodicity of more than two years whereas the last three columns use a split at the four-year frequency. Results are broadly the same irrespectively of the estimation approach used. Except for lowfrequency output growth all coefficients are significant. The coefficients on low-frequency money and output growth are roughly proportional in absolute value but with opposite signs. The last row in Table 3 gives the $p$-value from a test of the hypothesis that the long-run coefficients on money growth and output growth are unity and minus unity, respectively. This hypothesis is tested by a $F$-test for the single-equation approaches and by a likelihood-ratio test for the system estimation. Except in the case of the system estimates using a two-year threshold between the frequency bands the hypothesis of a unit long-run effect, as suggested by the quantity theory, cannot be rejected. Furthermore, the output gap has a positive effect on inflation as implied by standard Phillips-curve analysis. ${ }^{31}$

\section{Granger Causality}

While our results indicate that money growth is strongly correlated with current inflation, we have not directly tested the hypothesis that low-frequency movements in money growth cause inflation. This is important because the finding that money growth and inflation move together may simply reflect a stable money-demand function and need not imply that money growth causes inflation. To understand properly the inflation process an understanding of the patterns of causality is consequently needed.

We employ the notion of causality introduced by Granger $(1969,1980)$. Money growth is said to cause inflation if it contains information about future inflation that is not contained in some past values of $\pi$. The extent and direction of causality can differ between frequency bands (Geweke 1982, Granger and Lin, 1995). The fact that a stationary series is effectively the sum

30 In order not to be overly restrictive we do not impose the coefficients obtained in the previous section on equation (9), but reestimate all coefficients and test for the long-run validity of the quantity theory.

31 Woodford (2007) shows that a New-Keynesian Phillips curve model together with a standard money demand equation can generate the correlations between money growth and inflation that we stress. However, in contrast to in the Japanese data, money growth does not Granger cause inflation in Woodfords' model (see the discussion in the next section). 
of uncorrelated components, each of which is associated with a single frequency ordinate, allows the full causal relationship to be decomposed by frequency. ${ }^{32}$

Since the causal relation between money growth and inflation could be influenced by third variables, we follow Geweke (1984) and investigate Granger causality across frequencies in a vector autoregression (VAR) containing inflation, money growth, the output gap and the change in the logarithm of the interest rate, i.e. we condition on the output gap and the change in the log interest rate when measuring causality between $\pi_{t}$ and $\mu_{t}{ }^{33}$

The frequency-wise measure of causality suggested by Geweke (1982) and Hosoya (1991) is defined as:

$$
M_{\mu \rightarrow \pi \mid Z}(\omega)=\log \left[1+\frac{\left|\Psi_{12}\left(e^{-i \omega}\right)\right|^{2}}{\left|\Psi_{11}\left(e^{-i \omega}\right)\right|^{2}}\right],
$$

where $\Psi_{12}$ and $\Psi_{11}$ are obtained from the moving average representation of a VAR that includes the variables of interest (in our case $\pi_{t}$ and $\mu_{t}$ ) together with the conditioning variables, $Z_{t}$,

$$
\left[\begin{array}{c}
\pi_{t} \\
\mu_{t} \\
Z_{t}
\end{array}\right]=\left[\begin{array}{lll}
\Psi_{11}(L) & \Psi_{12}(L) & \Psi_{13}(L) \\
\Psi_{21}(L) & \Psi_{22}(L) & \Psi_{23}(L) \\
\Psi_{31}(L) & \Psi_{32}(L) & \Psi_{33}(L)
\end{array}\right]\left[\begin{array}{c}
\eta_{1 t} \\
\eta_{2 t} \\
\eta_{3 t}
\end{array}\right]
$$

where the $\Psi_{i j}(L), i, j=1,2,3$ are polynomials in the lag operator, $L$, and $\eta_{1}, \eta_{2}, \eta_{3}$ are the orthogonalized shocks. $^{34}$

Money growth Granger-causes inflation if $\Psi_{12}(L)$ is non-zero. Breitung and Candelon (2006) show that the hypothesis $M_{\mu \rightarrow \pi}(\omega)=0$ is equivalent to a linear restriction on the VAR coefficients and that its significance can be tested by a conventional Wald test. To assess the

32 Though the component of a series in a certain frequency band cannot be estimated without the use of a twosided filter which destroys the chronological aspect of the causal definition, it is possible to deduce causal relationships at different frequencies without estimation of the series' components, as it is done in the band spectrum regressions.

33 We do not condition on output growth and the output gap simultaneously since these variables are both derived from real GDP. Furthermore, since output growth is obtained by first-differencing the (logarithm of) output, most of the power at low frequencies is removed so the variable is uninformative about the direction of causality at business-cycle and lower frequencies.

34 That is, the VAR reduced-form errors are transformed into the orthogonalized errors by multiplying them with the lower triangular matrix from a Choleski decomposition of the reduced-form covariance matrix. 
significance of the causal relationship we compare the causality measure for $\omega \in(0, \pi)$ with the critical value of a $\chi^{2}$-distribution with two degrees of freedom, which is 5.99.

Figure 5 shows the causality measure over frequencies from zero to $\pi$. The Akaike criterion indicates a lag length of five for the VAR underlying the causality test. We find significant Granger causality from money growth to inflation at low frequencies, and again at frequencies above $0.6 \pi$, which corresponds to three quarters, whereas between 13 and 3 quarters no significant Granger causality is found. ${ }^{35}$ By contrast, there is no Granger causality from inflation to money growth at any frequency. We also test Granger causality from the output gap to inflation and conversely. The causal relationship from the output gap to inflation is significant except for frequencies between ten and five quarters and shows a peak at the business cycle frequency of 20 quarters. We thus find that output gaps predict inflation at higher frequencies than money growth.

\section{Conclusions}

The empirical work presented in this paper can be summarised as follows. First and most importantly, the band spectral regressions indicate that money growth is correlated - and output growth is inversely correlated - with inflation in the low frequency band, in particular when that is defined as frequencies of four years or more. Furthermore, that correlation reflects unidirectional Granger causality from money growth to inflation, implying that money growth does contain information about future inflation that is not already embedded in inflation. In the high frequency band the quantity-theoretic variables appear to be of little significance for inflation.

Second, and focussing on the case in which the distinction between high and low frequency is drawn at four years, the output gap is highly significant at high frequencies but not at low frequencies. Moreover, there is unidirectional Granger causality from the output gap to inflation.

Third, in modelling headline inflation it seems useful to focus on the low-frequency components of money and output growth, and on the output gap. The results indicate that in the long run, a one percentage point increase in the growth rate of money at low frequencies

\footnotetext{
35 Measuring frequency, $\omega$, in fractions of $\pi$, periodicity in quarters is given by $2 \pi / \omega$. Thus, a frequency of
} $\omega=0.1 \pi$ corresponds to a periodicity of 20 quarters. 
leads to an equal increase in headline inflation. An increase in the low-frequency component of output growth depresses inflation proportionally, as suggested by the quantity theory.

Fourth, the opportunity cost of holding M2+CD in Japan is better modelled by assuming that it is the logarithm of the interest rate, as opposed to the interest rate itself, that matters. The importance of this specification is clearest once data for the recent period of quantitative easing are considered.

While these results are supportive of the notion that money growth does contain information useful for predicting future inflation, since they say nothing about whether money growth is controllable, we emphasise that they do not imply that it would be desirable for the BOJ to target money growth. Nor do they imply that money growth should have any "special" status in the conduct of policy; like other macroeconomic variables, the weight attached to it in the policy process should presumably depend on how closely it is related to inflation.

Finally, we note that we have not explored whether the relationship between money growth and inflation is stable over time. The main reason for this is that since we focus on the lowfrequency relationship between the variables, there is in fact little information about that relationship and it is consequently difficult to test whether it has shifted over time. Of course, this is merely the econometric equivalent of the fact that, since the relationship between money growth and inflation involves "long and variable lags", it is difficult to know in real time whether and, if so, how the relationship has changed over time. 


\section{References}

Assenmacher-Wesche, Katrin and Stefan Gerlach (2006), "Interpreting Euro Area Inflation at High and Low Frequencies,” BIS Working Paper No. 195.

Assenmacher-Wesche, Katrin and Stefan Gerlach (2007a), "Understanding the Link between Money Growth and Inflation in the Euro Area," in: David P. Cobham (ed.), The Travails of the Eurozone, Palgrave Macmillan, Basingstoke, 10-39.

Assenmacher-Wesche, Katrin and Stefan Gerlach (2007b), "Money Growth, Output Gaps and Inflation at Low and High Frequency: Spectral Estimates for Switzerland," Journal of Economic Dynamics and Control, forthcoming.

Assenmacher-Wesche, Katrin and Stefan Gerlach (2007c) "Money at Low Frequencies," Journal of the European Economic Association 5, 534-542.

Bae, Youngsoo, Vikas Kakkar and Masao Ogaki (2006), "Money Demand in Japan and Nonlinear Cointegration,” Journal of Money, Credit, and Banking, 38, 1659-1667.

Baxter, Marianne and Robert G. King (1999), "Measuring Business Cycles: Approximate Band-Pass Filters for Economic Time Series," Review of Economics and Statistics, 81, 575593.

BOJ (2003), "The Role of the Monetary Stock in Conducting Monetary Policy," Bank of Japan Quarterly Bulletin, May, 151-202.

BOJ (2006), “The Bank’s Thinking of Price Stability,” Bank of Japan Quarterly Bulletin, May, $65-90$.

Bordo, Michael D. and Andrew J. Filardo (2005), "Deflation and Monetary Policy in a Historical Perspective: Remembering the Past or Being Condemned to Repeat It?," Economic Policy, 20, 799-844.

Bordo, Michael D. and Andrew J. Filardo (2007), "Money Still Makes the World Go Round: The Zonal View," Journal of the European Economic Association, 5, 509-523.

Breitung, Jörg and Bertrand Candelon (2006), "Testing for Short- and Long-Run Causality: A Frequency-Domain Approach," Journal of Econometrics, 132, 363-378.

Eggertsson, Gauti B. and Michael Woodford (2003), "The Zero Bound on Interest Rates and Optimal Monetary Policy,” Brooking Papers on Economic Activity, 1, 139-211.

Engle, Robert F. (1974), “Band Spectrum Regression,” International Economic Review, 15, $1-11$.

Friedman, Milton (1985), “The Fed's Monetarism was Never Anything but Rhetoric," Letter to the Editor, Wall Street Journal, December 18.

Fujiki, Hiroshi and Kiyoshi Watanabe (2004), "Japanese Demand for M1 and Demand Deposits: Cross-Sectional and Time-Series Evidence from Japan," Monetary and Economics

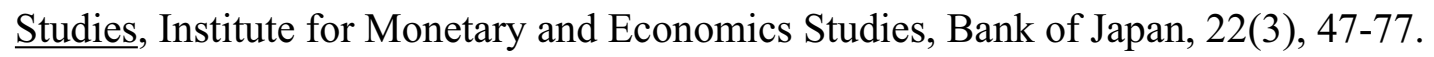


Fujiwara, Ippei (2006), "Evaluating Monetary Policy When Nominal Interest Rates are Almost Zero,” Journal of Japanese and International Economies, 20, 434-453.

Gerlach, Stefan (2003), “The ECB's Two Pillars,” CEPR Discussion Paper No. 3689.

Gerlach, Stefan (2004), "The Two Pillars of the European Central Bank," Economic Policy, 40, 389-439.

Geweke, John (1982), "Measurement of Linear Dependence and Feedback Between Multiple Time Series," Journal of the American Statistical Association, 77, 304-324.

Geweke, John (1984), "Measures of Conditional Linear Dependence and Feedback Between Time Series," Journal of the American Statistical Association, 79, 907-915.

Granger, Clive W. J. (1969), "Investigating Causal Relations by Econometric Models and Cross-Spectral Methods," Econometrica, 37, 424-438.

Granger, Clive W. J. (1980), “Testing for Causality: A Personal Viewpoint," Journal of Economic Dynamics and Control, 2, 329-352.

Granger, Clive W. J. and Jin-Lung Lin (1995), "Causality in the Long Run," Econometric Theory, 11, 530-536.

Hetzel, Robert L. (2004), "Price Stability and Japanese Monetary Policy," Monetary and Economics Studies, Institute for Monetary and Economics Studies, Bank of Japan, 22(3), 1-23.

Hosoya, Yuzo (1991), "The Decomposition and Measurement of the Interdependency between Second-Order Stationary Process," Probability Theory and Related Fields, 88, 429444.

Iwata, Kazumasa (2006), "The Role of Money and Monetary Policy in Japan," Speech given at the Fourth ECB Central Banking Conference on "The Role of Money: Money and Monetary Policy in the Twenty-First Century," held in Frankfurt on November 9-10, 2006.

Iwata, Kikuo (1993), Kinyu-Seisaku no Keizaigaku: Nichigin Riron no Kenshou [Economics on Monetary Policy: Examining the BOJ's Theory], Nihon Keizai Shimbun-sha, Tokyo (in Japanese).

Kimura, Takeshi (2001), “The Impact of Financial Anxieties on Money Demand in Japan," in: Hans-Joachim Klöckers and Caroline Willecke (eds.), Monetary Analysis: Tools and Applications, European Central Bank, Frankfurt, 97-116.

Kimura, Takeshi, Hiroshi Kobayashi, Jun Muranaga and Hiroshi Ugai (2003), "The Effect of the Increase in the Monetary Base on Japan's Economy at Zero Interest Rates: An Empirical Analysis,” BIS Paper, No. 19, 276-312.

Kitamura, Tomiyuki and Ryoji Koike (2003), "The Effectiveness of Forecasting Methods Using Multiple Information Variables," Monetary and Economics Studies, Institute for Monetary and Economics Studies, Bank of Japan, 21(1), 105-143.

Komiya, Ryutaro (1976), "Shouwa Yonju Hachi, Kyu Nen Infureshon no Geinin [Causes of the 1973-74 Inflation]," Keizaigaku Ronsyu, University of Tokyo, 42(1), 2-40 (in Japanese). 
Krugman, Paul (1998), “It's Baaack: Japan's Slump and the Return of the Liquidity Trap," Brooking Papers on Economic Activity, 2, 137-205.

Lee, Junsoo and Mark C. Strazicich (2003), "Minimum Lagrange Multiplier Unit Root Test with Two Structural Breaks," Review of Economics and Statistics, 85, 1082-89.

Lee, Junsoo and Mark C. Strazicich (2004), "Minimum LM Unit Root Test with One Structural Break," Department of Economics, Appalachian State University Working Paper No. 04-17.

Lucas, Robert E. (1980), "Two Illustrations of the Quantity Theory of Money," American Economic Review, 70, 1005-1014.

Maddala, G.S. and In-Moo Kim (1998), Unit roots, Cointegration, and Structural Change, Cambridge University Press, Cambridge.

Meltzer, Allan H. (2001), "Monetary Transmission at Low Inflation: Some Clues from Japan in the 1990s," Monetary and Economics Studies, Institute for Monetary and Economics Studies, Bank of Japan, 19, S-1, 13-34.

Miyao, Ryuzo (1996), "Does a Cointegrating M2 Demand Relation Really Exist in Japan?" Journal of Japanese and International Economies, 10, 169-180.

Miyao, Ryuzo (2002), "Liquidity Traps and the Stability of Money Demand: Is Japan Really Trapped at the Zero Bound?” RIEB Discussion Paper, No. 127, Kobe University.

Miyao, Ryuzo (2005), “Use of the Money Supply in the Conduct of Japan's Monetary Policy: Re-Examining the Time-Series Evidence,” Japanese Economic Review, 56, 165-187.

Murphy, Kevin M. and Robert H. Topel (1985), "Estimation and Inference in Two-Step Econometric Models," Journal of Business and Economic Statistics, 3, 370-379.

Nagayasu, Jun (2003), “A Re-Examination of the Japanese Money Demand Function and Structural Shifts,” Journal of Policy Modeling, 25, 359-375.

Nelson, Edward (2006), "The Great Inflation and Early Disinflation in Japan and Germany," Federal Reserve Bank of St. Louis Working Paper, 2006-052B.

Neumann, Manfred J. M. (2003), “The European Central Bank's First Pillar Reassessed," Unpublished working paper, University of Bonn.

Neumann, Manfred J. M. and Claus Greiber (2004), "Inflation and Core Money Growth in the Euro Area," Discussion Paper 36/2004, Deutsche Bundesbank.

Newey, Whitney K. and Kenneth D. West (1987), "A Simple, Positive Semidefinite, Heteroskedasticity and Autocorrelation Consistent Covariance Matrix," Econometrica, 55, 703-708.

Okina, Kunio (1993), Kinyu-Seisaku: Chuou Ginkou no Shiten to Sentaku [Monetary Policy: Views and Choices made by a Central Bank], Toyo Keizai Shimpo-sha, Tokyo. 
Pesaran, M. Hashem and Yongcheol Shin (1998), "An Autoregressive Distributed-Lag Modelling Approach to Cointegration,” in: Steinar Strom (ed.), Econometrics and Economic Theory in the 20th Century, Cambridge University Press, Cambridge, 371-413.

Sekine, Toshitaka (1998), "Financial Liberalization, the Wealth Effect, and the Demand for Broad Money in Japan," Monetary and Economics Studies, Institute for Monetary and Economics Studies, Bank of Japan, 16(1), 35-55.

Sekine, Toshitaka (2001), "Modeling and Forecasting Inflation in Japan," IMF Working Paper, WP/01/82.

Stock, James H. and Mark W. Watson (1993), "A Simple Estimator of Cointegrating Vectors in Higher Order Integrated Systems," Econometrica, 61, 783-820.

Suzuki, Yoshio (1985), "Japan's Monetary Policy Over the Past 10 Years," Monetary and Economics Studies, Institute for Monetary and Economics Studies, Bank of Japan, 3(2), 1-9.

Svensson, Lars E.O. (2003), "Escaping from a Liquidity Trap and Deflation: The Foolproof Way and Others," Journal of Economic Perspective, 17(4), 143-166.

Ugai, Hiroshi (2006), "Effects of the Quantitative Easing Policy: A Survey of Empirical Analyses," Bank of Japan Working Paper, No. 06-E-10.

Woodford, Michael (2007), "Does a 'Two-Pillar Phillips Curve" Justify a Two-Pillar Monetary Policy Strategy?," mimeo, http://www.columbia.edu/ mw2230/TwoPillars.pdf. 
Tables and Figures

Table 1. Unit root tests

Sample period: 1970Q1 to 2005Q4.

\begin{tabular}{lcccccc}
\hline & $A D F$ & $P P$ & $E R S$ & KPSS & SIC lag & Determ. \\
\hline Inflation & -2.60 & $-6.40^{*}$ & $-2.36^{*}$ & $1.67^{*}$ & 4 & $\mathrm{C}$ \\
Money growth & -2.04 & -2.04 & -0.98 & $9.94^{*}$ & 0 & $\mathrm{C}$ \\
Output growth & $-3.97^{*}$ & $-9.29^{*}$ & $-3.40^{*}$ & $1.26^{*}$ & 2 & $\mathrm{C}$ \\
Output gap & $-5.21^{*}$ & $-3.69^{*}$ & $-3.66^{*}$ & 0.05 & 3 & $\mathrm{C}$ \\
Log interest rate & 1.60 & 0.40 & 2.18 & $1.73^{*}$ & 5 & $\mathrm{C}$ \\
Change in log interest rate & $-8.25^{*}$ & $-9.85^{*}$ & $-8.14^{*}$ & 0.25 & 4 & $\mathrm{C}$ \\
Real money & -1.41 & -2.01 & -1.06 & $0.38^{*}$ & 5 & $\mathrm{~T}$ \\
Real money growth & $-5.00^{*}$ & $-6.22^{*}$ & $-3.28^{*}$ & 0.37 & 4 & $\mathrm{C}$ \\
Velocity & -3.26 & -2.08 & $-3.04^{*}$ & $0.25^{*}$ & 2 & $\mathrm{~T}$ \\
Velocity change & $-5.37^{*}$ & $-8.59^{*}$ & $-3.15^{*}$ & 0.07 & 6 & $\mathrm{C}$ \\
\hline
\end{tabular}

Note: The last column indicates the number of lags included in the test, which were chosen by the Schwarz information criterion (SIC). The last column indicates whether a constant (C) or a trend and a constant (T) are included in the test regression. The 5\% critical values for the tests including a constant (a trend) are $-2.89(-3.45)$ for the Augmented Dickey-Fuller (ADF) and the Phillips-Perron (PP) test, -1.95 (-2.89) for the Elliot, Stock and Rotenberg (ERS) test and $0.46(0.15)$ for the Kwiatkowski, Phillips, Schmidt and Shin (KPSS) test. An asterisk, “*”, indicates the rejection of the null hypothesis at the 5\% level. 
Table 2. Band spectrum regressions

Estimates of $\pi_{t}^{i}=\alpha_{\mu}^{i} \mu_{t-1}^{i}+\alpha_{\gamma}^{i} \gamma_{t-1}^{i}+\alpha_{g} g_{t-1}^{i}+\varepsilon_{t}^{i}, i=L F, H F$

Sample period: 1970Q2 to 2005Q4.

\begin{tabular}{lcccccc}
\hline & \multicolumn{2}{c}{ Low frequency: 2 to $\infty$ years } & \multicolumn{3}{c}{ High frequency: 0.5 to 2 years } \\
& $\begin{array}{c}\text { Unadjusted } \\
\text { money } \\
\text { growth }\end{array}$ & $\begin{array}{c}\text { Adjusted } \\
\text { money } \\
\text { growth }\end{array}$ & $\begin{array}{c}\text { System } \\
\text { estimation }\end{array}$ & $\begin{array}{c}\text { Unadjusted } \\
\text { money } \\
\text { growth }\end{array}$ & $\begin{array}{c}\text { Adjusted } \\
\text { money } \\
\text { growth }\end{array}$ & $\begin{array}{c}\text { System } \\
\text { estimation }\end{array}$ \\
\hline Money growth & $0.73^{* *}$ & $0.73^{* *}$ & $0.79^{* *}$ & -0.02 & 0.07 & 0.09 \\
Output growth & $(0.13)$ & $(0.13)$ & $(0.07)$ & $(0.21)$ & $(0.12)$ & $(0.19)$ \\
Output gap & $-0.99^{* *}$ & $-1.17^{* *}$ & $-1.32^{* *}$ & 0.09 & 0.08 & 0.08 \\
$\bar{R}^{2}$ & $(0.31)$ & $(0.36)$ & $(0.21)$ & $(0.14)$ & $(0.20)$ & $(0.13)$ \\
Degrees of freedom & $0.23^{* *}$ & $0.17^{*}$ & $0.16^{* *}$ & $0.43^{*}$ & 0.45 & $0.43^{*}$ \\
\hline Interest elasticity of & $(0.09)$ & $(0.09)$ & $(0.05)$ & $(0.21)$ & $(0.29)$ & $(0.19)$ \\
money demand & 0.54 & 0.59 & 0.60 & 0.10 & 0.11 & 0.12 \\
\hline
\end{tabular}

Low frequency: 4 to $\infty$ years High frequency: 0.5 to 4 years

Unadjusted Adjusted System Unadjusted Adjusted System money money estimation money money estimation growth growth growth growth

\begin{tabular}{lcccccc}
\hline Money growth & $0.85^{* *}$ & $0.93^{* *}$ & $0.88^{* *}$ & $-0.37^{*}$ & -0.05 & $-0.36^{*}$ \\
& $(0.20)$ & $(0.21)$ & $(0.05)$ & $(0.15)$ & $(0.10)$ & $(0.17)$ \\
Output growth & $-1.21^{* *}$ & $-1.62^{* *}$ & $-1.52^{* *}$ & -0.04 & -0.07 & -0.05 \\
& $(0.56)$ & $(0.61)$ & $(0.20)$ & $(0.10)$ & $(0.15)$ & $(0.10)$ \\
Output gap & 0.17 & 0.12 & $0.12^{* *}$ & $0.40^{* *}$ & $0.42^{* *}$ & $0.42^{* *}$ \\
& $(0.12)$ & $(0.13)$ & $(0.04)$ & $(0.10)$ & $(0.13)$ & $(0.10)$ \\
$\bar{R}^{2}$ & 0.61 & 0.71 & 0.76 & 0.17 & 0.13 & 0.07 \\
& & & & & & \\
Degrees of freedom & 14 & 14 & & 122 & 122 & \\
\hline $\begin{array}{l}\text { Interest elasticity of } \\
\text { money demand }\end{array}$ & -- & $-1.86^{*}$ & $-2.03^{*}$ & -- & $-1.86^{*}$ & -1.42 \\
\hline
\end{tabular}

Note: The dependent variable is the inflation rate at the respective frequency band. All variables are deviations from their sample means. ${ }^{*}$ indicates significance at the $5 \%,{ }^{* *}$ significance at the $1 \%$ level. For the regression using adjusted money growth we correct standard errors for the uncertainty related to the first-step estimate of the interest elasticity of money demand (see Murphy and Topel 1985). 
Table 3. Two-pillar Phillips curve

$$
\text { Estimates of } \pi_{t}=\beta_{\mu} \mu_{t-1}^{L F}+\beta_{\gamma} \gamma_{t-1}^{L F}+\beta_{g} g_{t-1}+\sum_{i=1}^{4} \beta_{\pi i} \pi_{t-i}+\varepsilon_{t}
$$

Sample period: 1970Q2 to 2005Q4.

\begin{tabular}{|c|c|c|c|c|c|c|}
\hline & \multicolumn{3}{|c|}{ Split at the 2-year frequency } & \multicolumn{3}{|c|}{ Split at the 4-year frequency } \\
\hline & $\begin{array}{l}\text { Unadjusted } \\
\text { money } \\
\text { growth }\end{array}$ & $\begin{array}{l}\text { Adjusted } \\
\text { money } \\
\text { growth }\end{array}$ & $\begin{array}{l}\text { System } \\
\text { estimation }\end{array}$ & $\begin{array}{l}\text { Unadjusted } \\
\text { money } \\
\text { growth }\end{array}$ & $\begin{array}{l}\text { Adjusted } \\
\text { money } \\
\text { growth }\end{array}$ & $\begin{array}{l}\text { System } \\
\text { estimation }\end{array}$ \\
\hline LF Money growth & $\begin{array}{c}0.21^{*} \\
(0.09)\end{array}$ & $\begin{array}{c}0.22^{* *} \\
(0.10)\end{array}$ & $\begin{array}{c}0.25^{*} \\
(0.11)\end{array}$ & $\begin{array}{c}0.21^{*} \\
(0.11)\end{array}$ & $\begin{array}{c}0.27^{*} \\
(0.13)\end{array}$ & $\begin{array}{c}0.23^{*} \\
(0.11)\end{array}$ \\
\hline LF Output growth & $\begin{array}{l}-0.24 \\
(0.18)\end{array}$ & $\begin{array}{l}-0.31 \\
(0.23)\end{array}$ & $\begin{array}{l}-0.34 \\
(0.23)\end{array}$ & $\begin{array}{l}-0.18 \\
(0.25)\end{array}$ & $\begin{array}{l}-0.35 \\
(0.32)\end{array}$ & $\begin{array}{l}-0.26 \\
(0.29)\end{array}$ \\
\hline Output gap & $\begin{array}{l}0.26^{* *} \\
(0.04)\end{array}$ & $\begin{array}{l}0.25^{* *} \\
(0.05)\end{array}$ & $\begin{array}{l}0.25^{* *} \\
(0.04)\end{array}$ & $\begin{array}{l}0.25^{* *} \\
(0.04)\end{array}$ & $\begin{array}{c}0.24^{* *} \\
(0.05)\end{array}$ & $\begin{array}{c}0.25^{* *} \\
(0.04)\end{array}$ \\
\hline $\begin{array}{l}\text { Sum of AR } \\
\text { coefficients }\end{array}$ & $\begin{array}{c}0.71^{* *} \\
(0.08)\end{array}$ & $\begin{array}{c}0.69^{* *} \\
(0.09)\end{array}$ & $\begin{array}{l}0.68^{* *} \\
(0.10)\end{array}$ & $\begin{array}{c}0.71^{* *} \\
(0.08)\end{array}$ & $\begin{array}{c}0.66^{* *} \\
(0.10)\end{array}$ & $\begin{array}{c}0.69^{* *} \\
(0.09)\end{array}$ \\
\hline $\bar{R}^{2}$ & 0.68 & 0.68 & 0.68 & 0.66 & 0.66 & 0.68 \\
\hline Durbin-Watson & 1.80 & 1.79 & 1.79 & 1.81 & 1.81 & 1.82 \\
\hline $\begin{array}{l}\text { Interest elasticity } \\
\text { of money demand }\end{array}$ & & $\begin{array}{l}-1.86^{*} \\
(0.84)\end{array}$ & $\begin{array}{l}-1.32 \\
(1.08)\end{array}$ & & $\begin{array}{l}-1.86^{*} \\
(0.84)\end{array}$ & $\begin{array}{l}-1.34 \\
(1.07)\end{array}$ \\
\hline $\begin{array}{l}\text { Test of unit long- } \\
\text { run coefficients }\end{array}$ & 0.47 & 0.22 & 0.00 & 0.58 & 0.37 & 0.11 \\
\hline
\end{tabular}

Note: The dependent variable is the headline inflation rate. All variables are deviations from their sample mean. Standard errors in parentheses; ${ }^{*}$ indicates significance at the $5 \%,{ }^{* *}$ significance at the $1 \%$ level. The last row shows the $p$-value from a test that the long-run coefficients of money growth and output growth are unity and minus unity, respectively. For the single-equation estimation we use a $F$-test, for the system estimation a likelihood ratio test. For the regression using adjusted money growth we correct standard errors for the uncertainty related to the first-step estimate of the interest elasticity of money demand (see Murphy and Topel 1985). 
Figure 1. Data
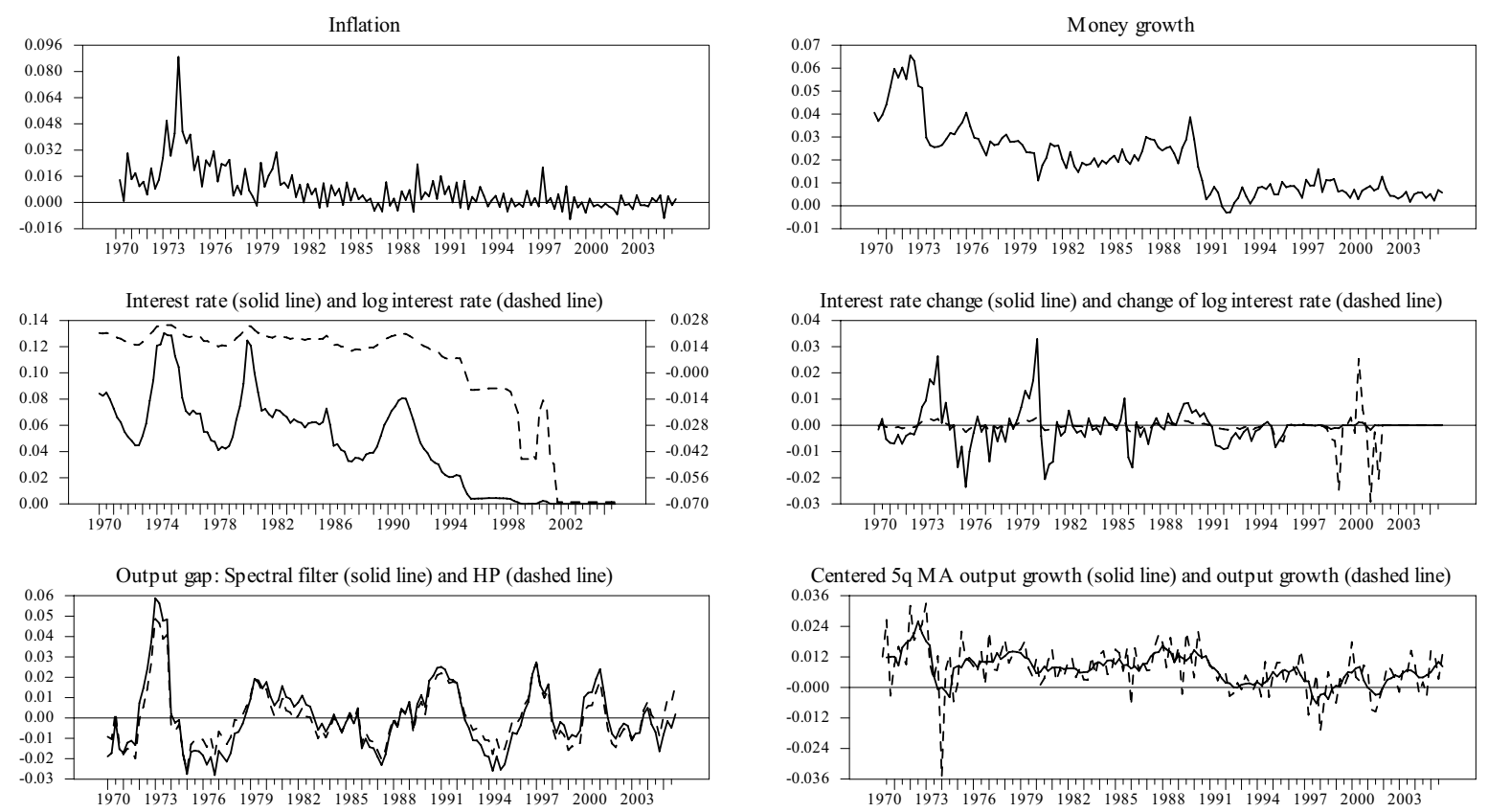

Figure 2. Inflation and money growth: low (left panel) and high frequency (right panel)
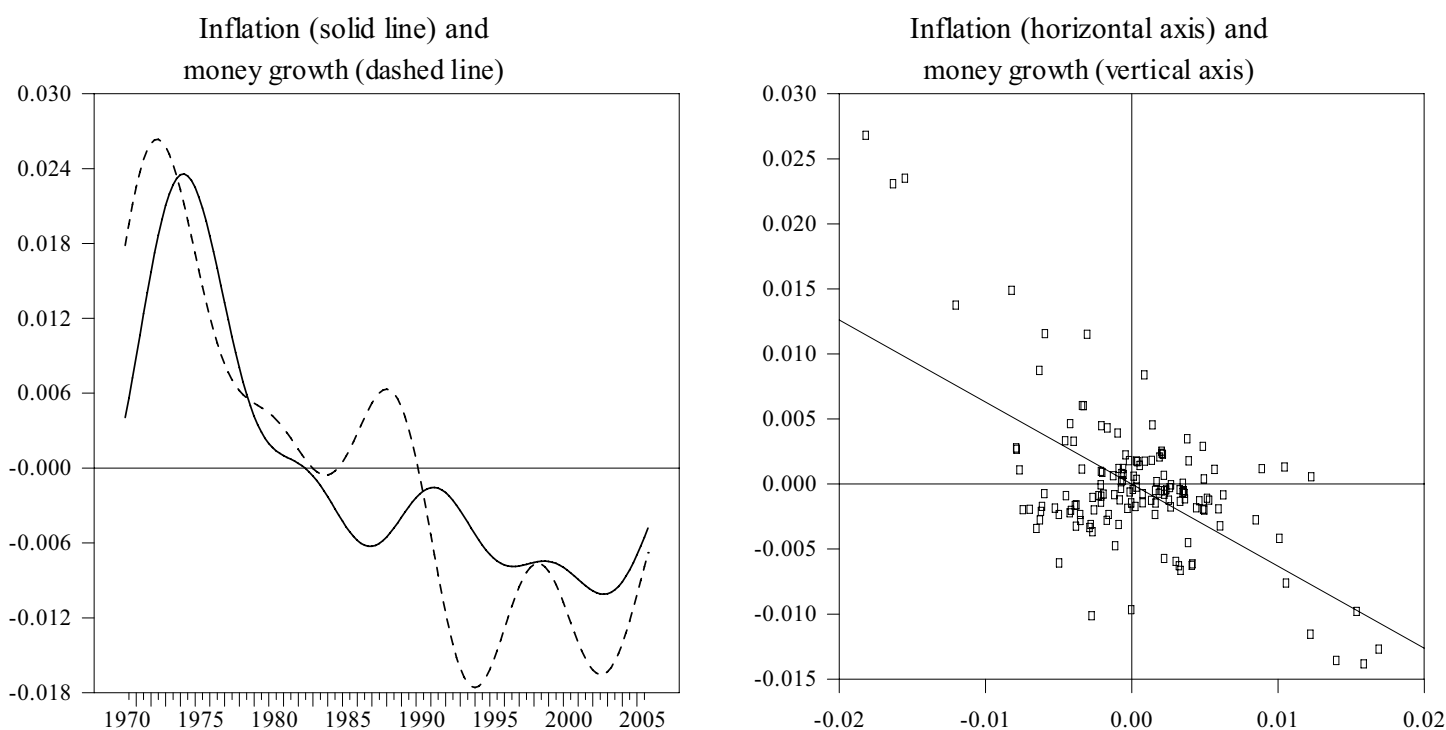
Figure 3. Inflation and output gap: low (left panel) and high frequency (right panel)
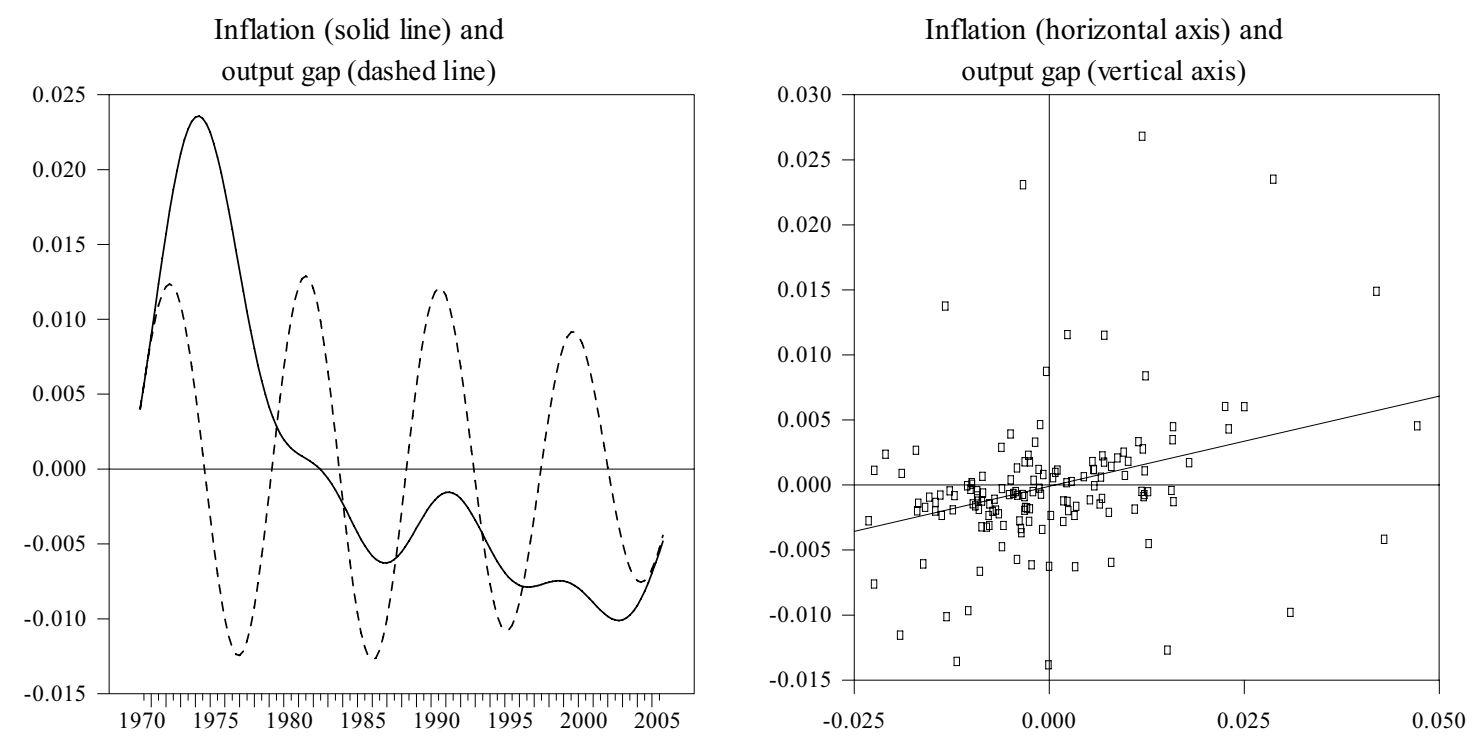

Figure 4. Interest elasticity of money demand
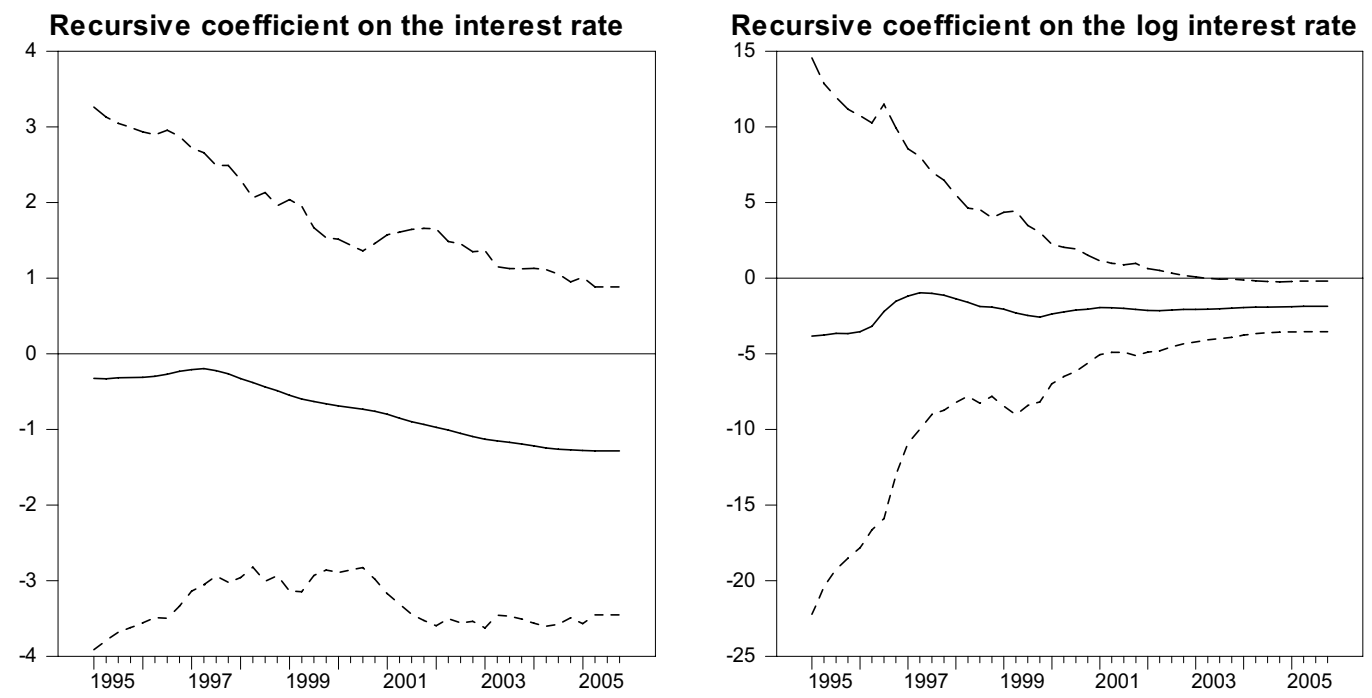

Note: The figure shows recursive estimates of the interest elasticity of money demand with their $95 \%$ confidence bounds, estimated by DOLS with two lags and leads of the differenced regressors and an AR(4) correction for the error term. 
Figure 5. Causality
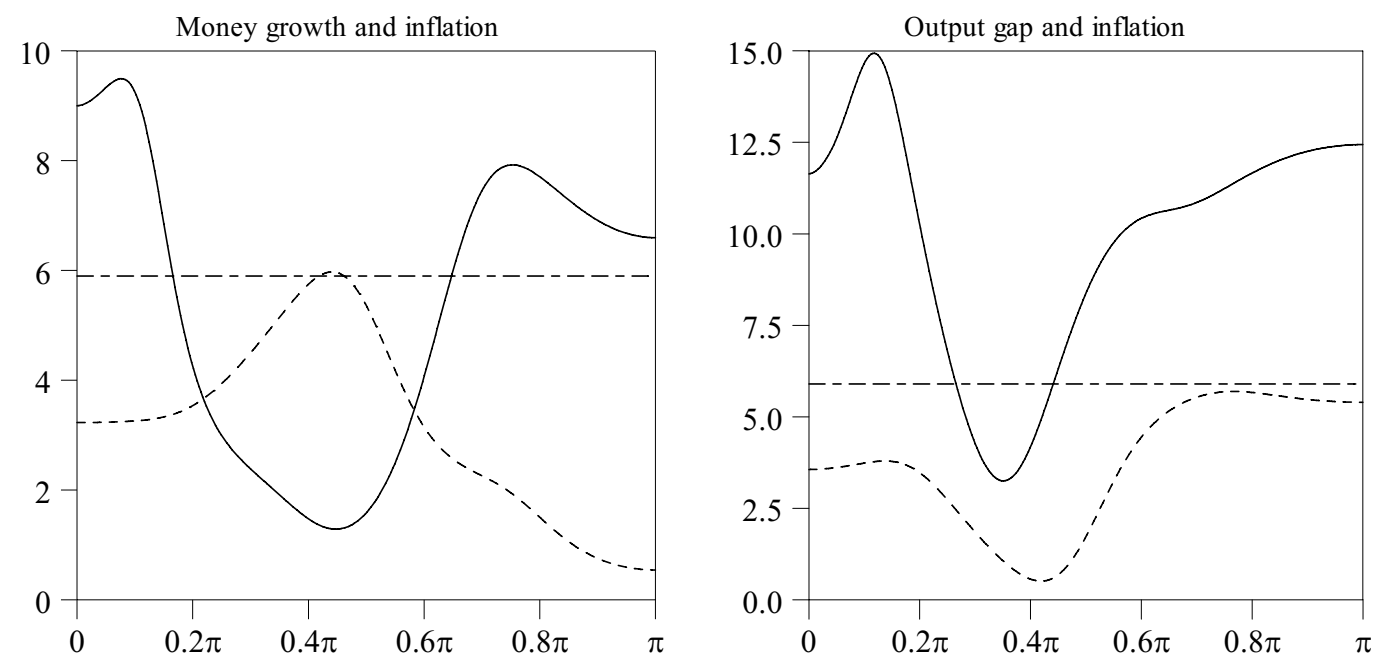

Note: The solid line shows the causality measure from money growth and the output gap to inflation, the dashed line the causality measure from inflation to the respective variable. The causality measures are derived from a VAR including inflation, money growth, the output gap and the change in the logarithm of the interest rate. The horizontal line represents the $5 \%$ critical value. The horizontal axis shows the frequency ordinates as fractions of $\pi$. 


\section{Swiss National Bank Working Papers published since 2004:}

2004-1 Samuel Reynard: Financial Market Participation and the Apparent Instability of Money Demand

2004-2 Urs W. Birchler and Diana Hancock: What Does the Yield on Subordinated Bank Debt Measure?

2005-1 Hasan Bakhshi, Hashmat Khan and Barbara Rudolf: The Phillips curve under state-dependent pricing

2005-2 Andreas M. Fischer: On the Inadequacy of Newswire Reports for Empirical Research on Foreign Exchange Interventions

2006-1 Andreas M. Fischer: Measuring Income Elasticity for Swiss Money Demand: What do the Cantons say about Financial Innovation?

2006-2 Charlotte Christiansen and Angelo Ranaldo: Realized Bond-Stock Correlation: Macroeconomic Announcement Effects

2006-3 Martin Brown and Christian Zehnder: Credit Reporting, Relationship Banking, and Loan Repayment

2006-4 Hansjörg Lehmann and Michael Manz: The Exposure of Swiss Banks to Macroeconomic Shocks - an Empirical Investigation

2006-5 Katrin Assenmacher-Wesche and Stefan Gerlach: Money Growth, Output Gaps and Inflation at Low and High Frequency: Spectral Estimates for Switzerland

2006-6 Marlene Amstad and Andreas M. Fischer: Time-Varying Pass-Through from Import Prices to Consumer Prices: Evidence from an Event Study with Real-Time Data

2006-7 Samuel Reynard: Money and the Great Disinflation

2006-8 Urs W. Birchler and Matteo Facchinetti: Can bank supervisors rely on market data? A critical assessment from a Swiss perspective

2006-9 Petra Gerlach-Kristen: A Two-Pillar Phillips Curve for Switzerland

2006-10 Kevin J. Fox and Mathias Zurlinden: On Understanding Sources of Growth and Output Gaps for Switzerland

2006-11 Angelo Ranaldo: Intraday Market Dynamics Around Public Information Arrivals

2007-1 Andreas M. Fischer, Gulzina Isakova and Ulan Termechikov: Do FX traders in Bishkek have similar perceptions to their London colleagues? Survey evidence of market practitioners' views 
2007-2 Ibrahim Chowdhury and Andreas Schabert: Federal Reserve Policy viewed through a Money Supply Lens

2007-3 Angelo Ranaldo: Segmentation and Time-of-Day Patterns in Foreign Exchange Markets

2007-4 Jürg M. Blum: Why `Basel II’ May Need a Leverage Ratio Restriction

2007-5 Samuel Reynard: Maintaining Low Inflation: Money, Interest Rates, and Policy Stance

2007-6 Rina Rosenblatt-Wisch: Loss Aversion in Aggregate Macroeconomic Time Series

2007-7 Martin Brown, Maria Rueda Maurer, Tamara Pak and Nurlanbek Tynaev: Banking Sector Reform and Interest Rates in Transition Economies: Bank-Level Evidence from Kyrgyzstan

2007-8 Hans-Jürg Büttler: An Orthogonal Polynomial Approach to Estimate the Term Structure of Interest Rates

2007-9 Raphael Auer: The Colonial Origins Of Comparative Development: Comment. A Solution to the Settler Mortality Debate

2007-10 Franziska Bignasca and Enzo Rossi: Applying the Hirose-Kamada filter to Swiss data: Output gap and exchange rate pass-through estimates

2007-11 Angelo Ranaldo and Enzo Rossi: The reaction of asset markets to Swiss National Bank communication

2007-12 Lukas Burkhard and Andreas M. Fischer: Communicating Policy Options at the Zero Bound

2007-13 Katrin Assenmacher-Wesche, Stefan Gerlach, and Toshitaka Sekine: Monetary Factors and Inflation in Japan 
Swiss National Bank Working Papers are also available at www.snb.ch, section Publications/Research Subscriptions or individual issues can be ordered at Swiss National Bank, Fraumünsterstrasse 8, CH-8022 Zurich, fax+41 4463181 14, E-mail library@snb.ch 